\title{
PHILOSOPHY - NOAH (1667) ON GOD AND NATURE
}

\author{
Wiep van Bunge
}

Noah, of Ondergang der Eerste Weerelt (Noah or Downfall of the First World) is the last play Vondel wrote, and he never saw it performed. Although it was published in 1667, it was probably written in 1665, when Vondel was turning 78 and had 14 more years to live. ${ }^{1}$ It really was the product of a Golden Age; in 1665 Vermeer painted the Girl With a Pearl Earring, Anthonie van Leeuwenhoek built his first microscope, and Spinoza started writing the Tractatus Theologico-Politicus (Theological-Political Treatise). These were indeed exciting times; the Philosophical Transactions of the Royal Society started appearing, Newton carried out his first optical experiments, after Cambridge University was temporarily closed on account of the plague, and Britain went to war with the Dutch Republic. In Paris, the first issue of the Journal des Sçavans appeared, while Racine published his Alexandre le Grand and Molière his L'amour médecin.

In view of the theological importance of the Flood and the astounding facts involved, the story of Noah had surprisingly little impact on the literary tradition of the Netherlands. While the Ark was depicted variously and repeatedly throughout Christendom from the first centuries onwards, Noah's story appears to have failed to inspire authors in the way Adam's had, let alone Moses's. ${ }^{2}$ From St. Augustine onwards, the story of the Flood and in particular the reconstruction of the logistics involved in shipping all the animals that Genesis purports were

\footnotetext{
${ }^{1}$ I use the edition made by Molkenboer in WB, 10, pp. 391-454. Act One, 1l. 43-44: 'The sixteen centuries and another fifty-six [sic] years / Have since then, feel free to boast, not passed fruitlessly'. ('De zestien eeuwen en noch zesenvijftigh [sic] jaeren / Zijn sedert, roemt vry, niet onvruchtbaer heengevaeren.') I owe all translations of Vondel's Dutch to Michiel Wielema, without whom this paper could not have been published in English.

${ }^{2}$ Fink, Noe der Gerechte in der frühchristlichen Kunst. For some early theological and scholarly assessments, see Garcia Martínez and Luttikhuizen, Interpretations of the Flood. In Allen, The Legend of Noah, pp. 151-53, Vondel is the only Dutch literary author (briefly) mentioned.
} 
saved had vexed a host of biblical scholars attempting to hold on to a literal interpretation of Noah's achievements. The limited lack of interest in the literary potential offered by the Flood also stands in stark contrast to early modern genealogical efforts to establish the holy lineage of the royal dynasties ruling Europe, all of whom were supposed to have descended from Aeneas and/or Noah. ${ }^{3}$ A rare precursor to Vondel's play appears to have been staged by Karel van Mander, who in the early 1570 s produced a Noah, the text of which is lost, however. ${ }^{4}$ Vondel's Noah does not seem to have inspired fellow Dutchmen to follow his lead either; the only major Dutch author who also turned to Noah was Willem Bilderdijk, who in 1820 published his own (uncompleted) Ondergang der eerste wareld. ${ }^{5}$

By the middle of the seventeenth century, wayward scholars such as Isaac La Peyrère and Isaac Vossius had started questioning the universality of the Flood as well as the chronological accuracy of the biblical account supplied in Genesis. ${ }^{6}$ Vondel, however, clearly did not want to be associated in any way with the harmful implications held by such scholarship regarding the infallibility of Scripture. An obvious clue as to Vondel's personal assessment of the relevance of Noah is to be found in its Dedication, in which the playwright declares it to be the final part of a trilogy; following Lucifer (1654) and Adam in ballingschap (1664), Noah (Vondel claims) completes the biblical account of the birth of evil and the outcome of its first encounter with man or, to put it another way, man's original response to the challenges presented to him by the lure of evil, only to be overcome by the making of a covenant, restoring God's confidence in man. ${ }^{7}$

\section{Noah or the Downfall of the First World}

The first act is set somewhere in the Caucasus, at the gates of 'Reuzenburgh', a castle inhabited by giants, the offspring of the up right sons of Seth and the mischievous daughters of Cain. These giants

3 Tanner, The Last Descendants of Aeneas.

${ }^{4}$ Langvik-Johannessen, Zwischen Himmel und Erde, p. 261.

Bilderdijk, Ondergang der eerste wareld, ed. Bosch.

6 Allen, The Legend of Noah, Chapters 4, 5 and 7.

Vondel's sources are clear: besides Genesis, he relies mainly on Jacob Salianus, Annales Ecclesiastici Veteris Testamenti, Tomus primus (Paris, 1619). The plays have been presented as a trilogy in the edition by Schenkeveld-van der Dussen. 
commit adultery on a gargantuan scale and revel in the practice of all sorts of other vicious crimes. In front of the castle we meet the antediluvian patriarch Noah, who is deeply concerned over the licentiousness of his contemporaries, and who is busy building a huge ship. Water is rising.

The next act introduces Achiman, 'ruler of the East', who is preparing his royal wedding to Urania and who is told by Noah's 'Bouwmeester' (Architect) that he had better prepare for a swim. The Architect also informs Achiman of Noah's precise plans and of his holy walk of life: he will ship his own family and had already stored pairs of all known animals. Soon he will sail away while the rest of the world will drown. Although his son Ham finds it difficult to obey his father, Noah's righteousness has kept his family intact. For a moment even Achiman seems impressed, upon which Noah appears, delivering his final warning: he is now 500 years old and for the last century he has been predicting that the end was nigh and all this time he has been working on his ship. Over the next few years water will flood the earth and darkness will fall, he prophesies, because the offspring of Seth and Cain was doomed and is only interested in sensual pleasures and material gain, and because it holds only the sword in reverence.

In the third act Achiman is forced to swallow his original libertine response to Noah's epiphany: as the water keeps rising and the first reports on drowning cattle reach him, he starts to recognise that Noah was, perhaps, right after all and he abandons the festivities at the Reuzenburgh. This leads to a violent reaction from Achiman's wife-tobe, Urania. She is furious and forces Achiman to swallow his hesitations. Suddenly Noah enters the scene and a dialogue ensues between Noah and Urania on the subject of women. Was not Noah born from a woman, does he not have a wife and daughters-in-law of his own? Urania boldly reminds Noah of his own father who was anything but prudent himself, but Noah retorts by declaring that he is committed to cleanse his family name.

At the opening of the fourth act we meet Noah's son Ham, who has apparently just been at the party and has spoken to Urania, and who now meets up with his father. Now that the Flood is about to wash away all living things, Ham questions the moral grounds on which God could possibly have decided to punish mankind in the way in which he is clearly about to. If you are right, Ham wonders, does that not turn God into a vengeful judge? His father tries to explain: firstly, Noah argues, we are simply unable to judge God's ways, and secondly, man 
has brought misery upon himself. Once Noah and his family have embarked, the Ark proves its worth and Noah turns his attention to Shem, continuing his argument that God cannot be blamed for the Flood: man is endowed with a free will, and has no one to blame but himself.

The fifth and final act brings us back to the court of Achiman. Lightning strikes, a giant flood is about to swallow the Reuzenburgh, and the archangel Uriel appears. Urania begs for mercy, and while it is certain that the entire court of Achiman will drown, the final words of Uriel proclaim that those who persevere in their repentance and are sincere in their remorse, will be saved and will receive God's grace after all. The chorus explains: they will have to wait until the coming of Christ, whose grace will allow them to leave purgatory for good.

\section{Theologians and Philosophers on the Origins of Evil}

Vondel was no theologian and no philosopher either, but as a playwright and a poet he did not back down from addressing major theological and philosophical issues. Arguably the most contested problem in seventeenth-century theology and moral philosophy concerned the nature of evil or, to be more precise, the assessment of man's part in what theologians used to refer to as 'sin'. By far the most important intellectual quarrel that was fought in the Dutch Republic during Vondel's lifetime was, of course, the dispute between Arminians or Remonstrants and Gomarists or Counter-Remonstrants. As will be only too familiar, the question of the responsibility for what is wrong with God's creation was at the heart of what started as an academic dispute between two Leiden professors of theology, but soon spilled over to the public domain, bringing the Republic to the brink of civil war. $^{8}$

A former Remonstrant himself, Vondel's stance toward this famous episode in Dutch church history is clear enough: he completely rejected the 'orthodox' Calvinism triumphant at the Synod of Dordrecht, according to which a correct understanding of God's sovereign grace left man utterly impotent.. According to 'Dordt', after the Fall man is

\footnotetext{
${ }^{8}$ See most recently Goudriaan and Van Lieburg, Re-examining the Synod of Dordt.

9 See Brom, Vondels geloof, esp. Chapter 3; Molkenboer, De jonge Vondel; Calis, Vondel, Chapters 5 and 6.
} 
sinful by nature and God's decision as to who will be saved cannot in any way be affected by the efforts of man. Any attempt to bring man's own achievements into the equation will inevitably harm the core of Reformed theology and lead to 'popish' speculations regarding a free will, or so Counter-Remonstrants argued. While the 'precise' wing of the Dutch Reformed church put all its cards on securing the sovereign nature of divine Grace, following from an essentially omnipotent God, their Remonstrant opponents continued to insist on the necessity to account for the origins as well as the reality of evil, that in view of God's essential benevolence could only be attributed to man. ${ }^{10}$

By the time Vondel wrote Noah, he had been a devout RomanCatholic for at least a quarter of a century and according to Catholic doctrine, and to the Jesuit point of view in particular, man is free to accept Grace or not, and good deeds - the possibility of which is subject to Grace itself - must be performed by the individual because that individual wants to perform them. Salvation, therefore, is always possible, but has to be earned. It should be added, though, that in the heart of French Catholicism Jansenism would raise the same issue that was under contention in Dordt, for the Flemish priest Cornelius Jansenius had come close to Calvinism in stressing that after the Fall man is no longer capable of doing any good deeds and grace cannot be earned. ${ }^{11}$ Although Jansenism made a considerable impact on Dutch Catholics, Vondel would have none of it. ${ }^{12}$

From a philosophical point of view, the question that split the Dutch Reformed Church during the 1610s and troubled French Catholicism until well into the eighteenth century revealed the difficulty of conceiving a Perfect Being that is omnipotent as well as perfectly benevolent. At the same time as Vondel was sitting down to complete his trilogy on the origins of human evil and its relationship to divine Grace, Spinoza, the greatest Dutch philosopher ever, was discussing the same subject in a remarkable bout of correspondence with Willem van Bleijenbergh, a grain merchant from Dordrecht, as is evident from Letters 18 to 24 in

${ }^{10}$ In the decades following Dordt the Remonstrant tradition would be upheld most convincingly by Vondel's personal friend Hugo Grotius to whom he dedicated Gysbreght van Amstel and by Simon Episcopius, to whom Vondel dedicated an epitaph: WB, 5, p. 242.

${ }_{11}$ Abercrombie, The Origins of Jansenism; Sedgwick, Jansenism in SeventeenthCentury France.

${ }^{12}$ Brom, Vondels geloof, pp. 324sqq.; Spiertz, 'Jansenisme in en rond de Nederlanden'; Roegiers, 'Jansenisme en katholieke hervorming in de Nederlanden'. 
Spinoza's correspondence. ${ }^{13}$ In assessing this episode in Spinoza's intellectual biography, it should be borne in mind that, except for a small circle of friends, the reading public were only able to acquaint themselves with his philosophical intentions in 1670. Prior to the (anonymous) publication of the Tractatus Theologico-Politicus, only Spinoza's debut was available, and since these Principia Philosophiae Cartesianae (Principles of Cartesian Philosophy, 1663) were supposed to serve as a general introduction to the metaphysics and the natural philosophy of Descartes, the wider public had to read between the lines in order to reconstruct the general thread of a budding 'Spinozism. ${ }^{14}$ To his credit, Van Blijenbergh, a staunch Calvinist, had come across several passages that caught his attention and made him curious to find out more, so he addressed Spinoza on 12 December 1664, wondering how he felt about the freedom of the will and its part in the origins of evil. In his first reply, Spinoza summarises the issue as follows:

it seems clearly to follow, both from God's providence, which is identical with his will, and from God's concurrence and the continuous creation of things, either that there is no such thing as sin or evil, or that God brings about that sin and that evil. ${ }^{15}$

While Spinoza is plainly very careful in this encounter with a perfect stranger from Dordrecht, he is adamant that in reality there is no such thing as 'evil' or 'sin', neither for that matter in Adam's behaviour:

Neither can we say that Adam's will was at variance with God's law, and was evil because it was displeasing to God. It would argue great imperfection to God if anything happened against his will, or if he wanted something he could not possess, or if his nature were determined in such a manner that, just like his creatures, he felt sympathy with some things and antipathy to others. ${ }^{16}$

In the next letter, Spinoza tries to explain to Van Blijenbergh that there is nothing 'positive' about evil, since it has no reality of its own, and is merely 'a mode of thinking' (ens rationis), construed by man,

${ }^{13}$ Spinoza, The Letters, transl. Shirley, pp. 128-72. See Deleuze, Spinoza, Chapter 3. On Van Bleyenbergh, see my entry in Van Bunge et al, The Dictionary of Seventeenth and Eighteenth-Century Dutch Philosophers.

${ }^{14}$ Officially, Spinoza's debut was entitled Renati Des Cartes Principiorum Philosophiae Pars I, et II, More Geometrico demonstratae. Accesserunt Ejusdem Cogitata Mataphysica generali, quam speciali occurrunt, quaestiones breviter explicantur (Amsterdam, 1663). A Dutch translation appeared in 1664.

${ }_{15}$ Spinoza, The Letters, p. 132.

${ }^{16}$ Ibid., pp. 133-34. 
'comparing things with one another. ${ }^{17}$ By this time, Spinoza must have felt that his philosophy, according to which 'that which constitutes the specific reality of evil, error and villainy does not consist in anything that expresses essence, ${ }^{18}$ could not possibly convince Van Blijenbergh, so he politely made an end to the correspondence. Of course, Spinoza's extremely rationalist 'solution' was only one of many attempts to account for the essence of evil launched by seventeenth-century philosophers, of which Leibniz's Theodicée (1710) would become the most famous example on account of its notoriously counterintuitive conclusion that we actually live in 'the best of all possible worlds'. ${ }^{19}$ In view of the great effort invested by contemporary theologians and philosophers, what, we might ask, did Vondel contribute to the ongoing debate concerning the nature of evil?

\section{Noah: God and Nature}

W.A.P. Smit was the first expert to draw attention to the merits of the remarkable fourth act of Noah, which according to earlier critics was a failure in that it slowed down the pace of the play. ${ }^{20}$ Smit readily admits that it does, but the reason for this, he argued, was a good one: by showing the effect Urania has on Ham, Noah's world becomes a far more dynamic one than might be expected from the dominant principle of the duality or dichotomy between Urania's domain and Noah's. The fourth act keeps the tension intact, Smit argues, but the conflict between the two acquires new depth once Urania proves to be able to strike at the heart of Noah's family, who are just about to embark, i.e. about to close the doors of the Ark. Furthermore, once Urania is told that ultimately she will not be lost forever either if her repentance is sincere, it could even be argued that a common future emerges.

Frans-Willem Korsten has pursued this observation as part of a highly ambitious interpretation of Vondel's entire legacy, according to which the latter's plays contain a sustained analysis of the sovereignty of potentia embodied in the desire to realise autonomy. ${ }^{21}$ Korsten similarly takes as his point of departure an analysis of Ham's questioning

17 Ibid., p. 153.

18 Ibid., p. 166.

19 Nadler, The Best of All Possible Worlds, Chapter 4.

20 Smit, Van Pascha tot Noah, 3, pp. 554-60.

21 Korsten, Vondel belicht, Chapter 2; Sovereignty as Inviolability, Chapter 2. 
God's impending punishment. As we saw in the fourth act, Ham is complaining about the injustice of God's punishment: what did we do to deserve the complete destruction of the world? Does not God himself show signs of 'female' fickleness by reacting in this way? Korsten, however, draws our attention to Noah's reply, in which it is revealed to Ham that Urania even attempted to cause a rift in his own family, by separating brothers and daughters in law from each other, and even father from mother: no other conclusion seems warranted than that Noah himself has come under the spell of Urania.

Riet Schenkeveld-van der Dussen has observed that Vondel repeatedly refers to events following the Flood, and more specifically to the famous passage in Genesis 9:18-26 in which Noah will be found naked and drunk after he tasted the wine he made from the grapes planted once the Ark has touched land again. Korsten has further explored the ambiguities simmering beneath the surface of Noah's encounter with Urania. ${ }^{22}$ To begin with, Noah's future behaviour clearly demonstrates that God failed to cleanse the world: even his most loyal servant succumbs to temptation at the first occasion that presents itself once the Ark has reached dry land. Is God ultimately unable to control Nature?

Consider the remarkable opening speech of the play, delivered by Apollion, who is supposed to represent Evil: it pictures the world after the Fall - a world in which all of nature enjoys a wide variety of the most lurid pleasures. Clearly, this situation was far from perfect, yet Genesis 6:5 carries little information on the matter: men have become evil, but what exactly does this evil amount to? According to Noah, antediluvian man was living lawlessly (1l. 389-400) and in sexual anarchy (ll. 431-506). It should be added, though, that Vondel appears to depict this sorry state of affairs with considerable relish:

Here sensual desire finds everything that human lust yearns for, Beautiful gardens, meadows, brooks and springs all around.

Fruits drop from the branches right into your mouth

And melt on your tongue. Birds warble.

Dancing, playing, endless feasting

And wedding celebrations are the custom here throughout the year.

Men's souls are not constrained by laws or subject to coercion. ${ }^{23}$

${ }_{22}$ Vondel, Lucifer, Adam in ballingschap en Noah, ed. Schenkeveld-van der Dussen, pp. 318-19.

${ }_{23}$ 'Hier vint de snoeplust al wat 's menschen lust loopt zoeken, / Lusthoven, beemden, beek en bronnen in het ront. / De vruchten druppen van de takken in den mont, / En smilten op de tong. de vogels quinkeleeren. / Het danssen, speelen, het gedurigh 
What is more, the real chaos pictured in Noah results from God's decision to make an end to this lawless life of pleasure, this abundance of potentia, and it is only natural that the violence with which God will destroy the First World provokes indignation with Noah's sons Ham, Shem and Japheth (1l.1032-54; 1289-1301; 1505-34): by what right does God decide to end the existing order of nature? Consider also Achiman's remarkable eloquence, where he points out how natural it is for a man to seek the company of beautiful women:

Freed of discipline and severe constraints, we find joy In passing the time that is now fully ours to dispose of. It pleases us to exercise these limbs, now full of youth and health, And not, tortured by rigid shackles, with a melancholy mind And our heads hanging low, to lament, to weep.

Pour out wine. Bring balsam. Rejoice. This is our moment. Make garlands of roses. Put a bride on each knee Before our time runs out and death closes the door. If father likes, let him play the tune to which we dance.

A youthful heart should miss neither feast nor a chance to wed. ${ }^{24}$

By the same token, there's something undeniably splendid about Urania's reaction to the first account of impending doom:

If due to this teaching men start to live woman-less

Then for sure things have gone far enough.

There is no need to drown the world in a flood of water:

For it cannot persist without women. (1l. 766-70) ${ }^{25}$

And then there is Urania's violent reaction to Achiman's refusal, in Act III, to continue with the wedding. Indeed, her indignation is perfectly natural and seems even justified: what nonsense to keep women responsible for what might be wrong with the world if men and women enjoyed themselves together, and what is more, is Achiman really about to break his promise to her?

banketteeren, / En bruiloften gaet hier het gansche jaer in zwang. / Men bint de zielen aen geen wetten, en bedwang' (ll. 68-74).

${ }_{24}$ 'Het luste ons 's levens tijt, nu tijdigh en voorhanden, / Te bezigen, ontboeit van tucht en strenge banden. / Het luste ons deze leên, nu jeughdigh en gezont, / Te bezigen, en niet, geprangt door naeu verbont, / Zwaermoedigh, hangends hoofts, te jammeren, te treuren. / Schenkt wijn. brengt balssem. juicht. het magh ons nu gebeuren. / Vlecht roozekranssen. zet op elke knie een bruit, / Eer's levens tijt verloop', de doot den draeiboom sluit'. / Belieft het vader, hy magh speelen, daer wy danssen. / Een jeugdigh hart verzuim' noch feest noch bruiloftskanssen.' (ll. 493-502).

25 'Begint het mansdom door dees leering vrouweloos / Te leven, zeker 't is dan ver genoegh gekomen. / Men hoeft de weerelt in geen zee en waterstroomen / Te smooren: want zy kan niet vrouweloos bestaen.' (11. 766-70) 
We reclined, our mouths touching, our arms locked in embrace,

Two souls fused and merged into one.

How did you not swear that you would rather see the sun

Robbed of its light than love's flame quenched in your bosom. ${ }^{26}$

But there is more to come, for Urania's ensuing cross-examination of Noah is surely one of the highlights of the entire play, delivering a perfectly self-confident declaration of independence:

And is this foolishness going to continue? Old man,

You are fretting yourself to death. What have you gained

All your life other than strife, nothing of value!

How can you think so badly of women?

A woman has borne you, her love in childbearing obliges you

To be faithful: and your sons, devoted to women,

Rather behold her face than the most beautiful thing,

That is the face of the all-warming sun,

The joy of the living and source of every light:

Or has old age withered away your desire for women,

Then your senility and not any woman is to blame. ${ }^{27}$

And listen to the song Urania and her friends sing when they return to the wedding party, celebrating the swan, a noble symbol of love, a beautiful animal that cannot drown. It would seem, then, that these women refuse to be intimidated by Noah's bleak message of repentance:

If all things sunk and perished

Where would the swan be?

Where would the swan be,

The swan, that joyful water creature,

Never tired of kissing?

No waters put out

Her burning passion.

She likes to nest midstream.

26 'Wy hingen, mont aen mont, en arm in arm gestrengelt, / Twee zielen beide in een gesmolten en gemengelt. / Wat zwoertge niet! de zon van straelen eer berooft / Te zien dan 't minnevier in uwe borst gedooft.' (ll. 875-79)

27 'En blijft dees suffery noch duuren? oude knecht, / Gy suft u selven doot. wat hebtge toch gewonnen / Uw leven lang, als twist gerokkent, niet gesponnen! / Hoe staen de vrouwen u zoo byster in het licht? / Een vrou heeft u gebaert, haer liefde uw trou verplicht / Door kinderbaeren: en uw zoons, verknocht aen vrouwen, / Haer aenschijn liever dan het allerschoonste aenschouwen, / Dat is het aenschijn van d'alkoesterende zon, / Der levendigen vreught, en aller lichten bron: / Of is door ouderdom uw vrouwezucht gesleeten, / Dat werde uw' ouderdom, en geene vrou geweeten.' (1l. 962-73) 
She nurtures passion,

She nurtures passion

With her merry mate,

And sits on her eggs,

And neither cares for weepers,

Nor fears any harm.

Her flying young swim along,

Over river and sea,

Over river and sea.

She lives in the element full of motion,

And cleans her feathers,

And glides with striding gait

Till the end of her life.

Dying she sings a merry song

Among the reeds,

Among the reeds.

She defies spiteful death out of lust for life,

With her song

And triumphant air,

And dies calmly.

Dying, her fading eyes

Seek again the light,

Seek again the light,

The dowry, nature's loan

Given to each,

To live in joy.

Thus she departs. ${ }^{28}$

Surely this passage, packed with melancholy, reveals a wisdom of its own, which reaches well beyond the blind pursuit of physical pleasure. If Urania and her companions are to be deemed 'hedonists', there is an undeniable dignity in the way they face their end. Ham's anger, as expressed in the fourth act, is just as well put, and even manages to make fun of God's motives: has He turned into a woman?

28 'Zou het al zinken en vergaen, / Waer bleef de zwaen? / Waer bleef de zwaen, / De zwaen, dat vrolijke waterdier, / Noit zat van kussen? / Geen watren blussen / Haer minnevier. / 't Lust haer te nestlen op den vloet. / Zy queekt den gloet, / Zy queekt den gloet / Met haere vrolijke wederga, / En kipt haere eiers, / En acht geen schreiers, / Noch vreest geen scha. / Vliegende jongen zwemmen me, / Door stroom en zee, / Door stroom en zee. / Zy groeit in 't levendigh element, / En wast de veêren, / En vaert spansseeren / Tot 's levens endt. / Stervende zingtze een vrolijk liet / In 't suikerriet, / In 't suikerriet. / Zy tart de nijdige doot uit lust, / Met quinkeleeren, / En triomfeeren, / En sterft gerust. / Stervende zoekt haer flaeu gezicht / Noch eens het licht, / Noch eens het licht, / Den bruitschat, van de natuur te leen / Aen elk gegeven, / Om bly te leven. / Zoo vaertze heen.' (ll. 1059-93) 
You do not install a father but an executioner,

Who counts every fault, scrupulously weighs each crime,

And threatens people's lives with a bare sword.

You portray the deity as a wild bear.

A bear, a wild boar uproots some bushes,

A tyrant an empire, the divinity all empires,

Nay the whole world. Whoever saw greater injustice!

Such an accumulation of waters and clouds,

Gradually and powerfully building up in the air,

When it bursts nations and mountains together will drown,

And we shall hear the world expire in one last gasp.

Does God become angry and infuriated, like a woman?

Is God's providence affected by remorse?

That's not providence but a disorder, inconstant,

And fickle. Have mercy on yourself first. ${ }^{29}$

Noah's response to Urania's proud defiance and to Ham's probing questions seems feeble. In reply to his sons, Noah claims that God could have forgiven man before the Flood, but that God's essence is incomprehensible. All we can do is guess:

I know, God be praised, that we lack the powers

To speak without stammering about God's nature,

Something incomprehensible, subject to no alteration.

One must grasp God's attributes by way of human speech. ${ }^{30}$

God's revenge, however, is justified since man has sinned out of free will (1. 1355) and because God's sovereignty, that is his potestas, enables him to take revenge:

When lately heaven's judge sternly opened court,

Where God's justice and God's mercy pleaded their cause,

His offended majesties could not be reconciled:

They stood in each other's light.

No verdict was spoken as long as the scales were balanced.

29 'Gy zet geen' vader, maer scherprechter op den troon, / Die elke struikling telt, de misdaet naeu wil weegen, / En dreigen 's menschen hals met eenen blooten deegen. / Gy beelt de godtheit uit, gelijk een' wilden beer. / Een beer, een everzwijn rukt een bosschaedje neêr, / De dwingelant een rijk; de godtheit alle rijken, / Ja al de weerelt. wie zagh grooter ongelijken! / Zoo veele wateren en wolken aengezakt, / En aen de lucht allengs met kracht op een gepakt, / Aen 't scheuren, zullen volk en bergen teffens smooren, / Wy's weerelts jongsten snik, in eenen dootsnik hooren. / Wort Godt verbolgen en oploopende, als een vrou? / Wort Godts voorzienigheit geraekt van naberou? / Dat 's geen voorzienigheit, maer krankheit, ongestadigh, / En wispeltuur. ay zijt u zelven eerst genadigh.' (ll. 1211-25)

${ }_{30}$ 'Ik weete, Godt zy lof, dat krachten ons ontbreeken / Om zonder stameren van Gods natuur te spreeken, / Een onbegrijpzaemheit, geen steurnis onderdaen. / Men moet door 's menschen spraek Godts eigenschap verstaen.' (ll. 1232-35) 
Finally anger proved weightier.

The curse prevailed after blessing's downfall,

And humankind, seeking in vain to extenuate its atrocities,

Was harshly punished and sent to its doom. ${ }^{31}$

Apparently this suffices to convince Noah's sons to embark: God is capable of destroying nature, and therefore he is entitled to do so.

As a consequence, we are left with a view of human history that is marked by the continuing movement between two opposing forces of Nature and Grace, which are not mutually exclusive, however, for while nature does not appear to be evil by itself, God's benevolence is not obvious either. In the end, God's potestas overrules nature's potentia. And while nature will not be overcome by God's decision to cleanse Noah's world from 'sin', God's interference with the natural order of things does not end with the Flood, which will only turn out to be a first step toward the coming of Christ, at which point even Urania will be saved. Let us see how far a more thorough exploration of the ambiguities contained in this conclusion may bring us, for it just so happens that Vondel's mature meditations on the dialectics of Nature and Grace originated at the dawn of the Radical Enlightenment. In 1665, when Spinoza started writing the Tractatus (and was trying to escape from Van Blijenbergh's prying eyes), half of his Ethics had been completed.

\section{Vondel versus the Radical Enlightenment}

Vondel was definitively no Spinozist. As Fokke Akkerman put it: 'One might ask whether a concept of tragedy is at all conceivable in the rigid deterministic system of Spinoza. He does not acknowledge a personal God as the ultimate foundation of morality, he does not believe in fate or chance. Everything that is or happens results from causes with inevitable necessity. ${ }^{32}$ On the other hand, Vondel's thought is in no way 'part of' the Radical Enlightenment, but in a play such as Noah, Korsten argues, Vondel 'thinks by acting, for literature is always part of a universe in which words, ideas and concepts constantly evolve and acquire

31 'Toen 's hemels rechter streng ter jongste vierschaer ging, / Daer Godts rechtvaerdigheit en Godts genade pleitten, / Kon geen verzoening by gequetste majesteiten / Verworven worden. d'een stont d'andere in het licht. / De tong der weeghschael zweegh, zoo langze in tegenwight / Bleef twijnen. entlijk quam de boosheit toverweegen. / De vloek stont boven, na het zwichten van den zegen, / En 't menschdom, dat vergeefs zijn gruwelen verbloemt, / Wert door het vonnis streng der straffe toegedoemt.' (ll. 1367-75)

32 Akkerman, 'A Spinozistic Perspective', p. 174. 
meaning in the continuing interaction between the text, its surroundings, and its readers. ${ }^{33}$ As soon as Vondel turns to the language of theology and philosophy, he rejects the Radical Enlightenment emphatically, as is evident from his Bespiegelingen van Godt en Godtsdienst (Reflections upon God and Religion), a long five-part poem, packed with arguments against the 'ongodisten' (the irreligious) and first published in 1662 . It was probably completed as early as $1659 .{ }^{34}$ From the nineteenth century onwards experts have discussed the issue of whether this text was indeed, as its editor Molkenboer argued, a reply to the budding thought of the young Spinoza. ${ }^{35}$ I see three reasons for subscribing to Molkenboer's suggestion: (a) the specificity of the equation of God and Nature as criticised by Vondel; (b) our present, increased awareness of the part Franciscus van den Enden played in Spinoza's circle of friends - Vondel knew Van den Enden well; (c) Filippo Mignini's reconstruction of Spinoza's early career as a philosopher - by 1660, it would seem, Spinoza had composed both the (unfinished) Tractatus de Intellectus Emendatione (Treatise on the Emendation of the Intellect) and the Korte Verhandeling (Short Treatise). For now we are, I feel, best advised to consider the Bespiegelingen as indeed being a first refutation not so much of Spinoza but of his 'circle' - if the Bespiegelingen were indeed completed before the 1660s, it is simply impossible to identify any single author as the leader of the Amsterdam circle of freethinkers that must have been active from the late 1650s onwards and of which both the young Spinoza, banned from the Jewish community of Amsterdam in 1656, as well as his teacher Franciscus van den Enden, were prominent members. ${ }^{36}$

${ }^{33}$ Korsten, Vondel belicht, p. 58; Sovereignty as Inviolability, p. 59, and more in general Chapter 1.

${ }^{34}$ WB, 9, pp. 406-653.

${ }_{35}$ Molkenboer's claims were prepared by De Valk, 'Vondel en Spinoza', and rejected simultaneously by Leemans, 'Vondel en Spinoza' and Zijderveld, 'Heeft Vondel Spinoza bestreden?'. Molkenboer replied in: 'Heeft Vondel Spinoza niet bestreden?', which provoked a final reply by Zijderveld: 'Kantteekeningen bij Prof. Molkenboer's verweer'.

${ }^{36}$ Mignini, 'Données et problèmes de la chronologie spinozienne entre 1656 et 1665'. Remarkably, Vondel's intervention is ignored by Gullan-Whurr, Within Reason: A Life of Spinoza, as well as by Nadler, Spinoza. Besides Van den Enden, one other member of the Amsterdam group of freethinkers active around 1660 also deserves to be mentioned in this context, although he probably did not belong to Spinoza's and Van den Enden's 'inner circle' and is (again) ignored by Gullan-Whurr and Nadler: Jan Pietersz. Beelthouwer. For as early as 1661 he published the crudely pantheist De Hoogste en Laetste bedenckingen over Godt, en Goddelicke Saken, and in 1664 he also wrote a pamphlet against Vondel, entitled Adams Antwoort tegen Joost van den Vondel over Adam in Ballingschap. See Meinsma, Spinoza en zijn kring, p. 243; Zilverberg, 'Jan 
Akkerman even feels that Vondel and Spinoza simply must have known each other. ${ }^{37}$

Since man is by nature endowed with reason, Vondel argues, denying God's existence is as irrational as it is unnatural, although the traditional a priori arguments in favour of God's existence fail to convince, since God's essence is beyond our grasp (I, 348). As a consequence, God's existence has to be demonstrated a posteriori, that is from His 'work' (I, 367). This, of course, is perfectly in tune with Aquinas, whom Vondel appears to follow closely, for instance where he arrives at the conclusion that God must be considered the 'unmoved mover' of the created universe:

But reason does not permit an infinite regress;

It comes to a halt before the omnipotence of the Mover

Who is never moved: for in the concatenation of things

No thing can set in motion another thing

Except through the agency of a first power, as a staff

Moves a stone through someone's hand: thus we meet

With a Mover who is himself at rest. ${ }^{38}$

Once God's existence has been established, Vondel feels free to launch his attack on the atheists, who call nature God (I, $521 \mathrm{ff}$.). Still in line with Thomist tradition, Vondel analyses the various meanings of 'nature.' Firstly, it refers to the essence of substances, secondly to the 'body' of the universe as whole, thirdly to its 'order', and finally to its laws. If God is called Nature insofar as He is considered the first cause of Nature, i.e. 'natura naturans', no problems need arise. However, as soon as God's natural effects or products are identified with His essence, atheism becomes inevitable (I, 603). God is infinite, Nature is not:

The creator and his work are two, not one and the same:

So the difference between both remains infinite. ${ }^{39}$

Pieterszoon Beelthouwer (c. 1630-c. 1669) en de joden'; Van Bunge, Johannes Bredenburg, pp. 184-87; Bordoli, Ragione e Scritura tra Descartes e Spinoza, pp. 245-56. Beelthouwer also makes a brief appearance in Israel, Radical Enlightenment, p. 204.

${ }^{37}$ Akkerman, 'A Spinozistic Perspective', p. 174.

38 'Doch reden laet niet toe onendigh voort te gaen; / Zoo blijft men voor de maght des albewegers staen, / Die noit bewogen wiert: want in het ommevoeren / Der dingen kan geen tweede iet anders ommeroeren / Dan door een eerste maght; gelijck de staf een' steen / Beweeght door iemants hant: dus stuit men dan op een' / Beweger, die zelf rust.' (I, 395-401)

39 'De schepper en het werck zijn twee, niet eenerley: / Dus blijft het onderscheyt oneindich tussen bey' (I, 931-32). 
Vondel frequently rebukes classical authors such as Democritus, Epicurus and Lucretius, and some of his arguments hit ancient and modern 'atheists' alike (see the lines in which he criticises the denial of divine providence, III, $43 \mathrm{ff}$.), but in particular his insistence on the need to distinguish God from his 'effects' (see also II, 234-36) clearly suggest concern about contemporary atheism, especially once he sets out to argue that being an 'unmoved mover' God cannot be understood to have any cause, so neither can God be conceived of as causa sui (II, 946). The same holds for his explicit defence of the Mosaic authorship of the Pentateuch $(\mathrm{V}, 94)$. And although there are some passages in which echoes of Descartes can be heard, ${ }^{40}$ Vondel's remarks concerning the impossibility of defining the essence of the soul and of arguing 'mathematically' concerning its immortality do not suggest great sympathy for Cartesianism:

But to show the immortality of the soul merely by the light

Of reason and nature, as in a view from afar,

To the understanding, since people's eyes

Cannot see the soul's essence:

The gracious reader will forgive me for being

Brief in my demonstration, so as not to cover this soul-paper

With sounds that weakly vanish

And seem more clever than profound.

The reasoning that is down-to-earth is too crude,

The proof that slips through your fingers too poor:

The middle way is sound. In affirming a truth

So necessary one should observe brevity and clarity

As far as the nature of the matter permits: for if

Mathematics were demanded here to make demonstrable,

Through measurement and number, the nature of the souls,

Which never, like the body, befell the fate of mortality:

That would be an error. Let no-one demand from reason

A clearer day than the matter can naturally give.

And this satisfies a heart that does not, like those too blind to see,

Demand tangible evidence, which cannot here be found. ${ }^{41}$

${ }^{40}$ Van Otegem, 'Vondels bespiegelingen over de nieuwe filosofie'.

${ }_{41}$ 'Maer om d'onsterflijckheit der ziele alleen door't licht / Van reden en natuure, als in een veergezicht, / Te toonen aen 't verstant; dewijl des menschen oogen / Het wezen van de ziel geensins aenschouwen mogen; / Zoo zal een heusche my verschoonen, dat ick hier / Beknopt ben in 't bewijs, om niet dit zielpapier / Met klancken te beslaen, die krachteloos verdwijnen, / En meer scherpzinnigheên dan grontbewijzen schijnen. / De reden is te grof, die laegh langs d'aerde kruipt, / Het grontbewijs te dun, dat door de vingers druipt: / De middelmaet houdt stant. in 't stercken van een waerheit / Zoo noodig, dient gelet op bondigheit, en klaerheit; / Behoudens naer den aert der stoffe: 
It is also in the Bespiegelingen, and more in particular in the analysis provided in this scholarly poem of the freedom of the will, that Vondel comes closest to answering the question as to how an omnipotent God can allow the existence of evil (II, 1113-22; 1219-36 and IV, $317-27) .{ }^{42}$

\section{Noah: Conclusion}

Once Vondel abandons the vocabulary of Scholasticism, however, and starts to reconnoitre the polyphony of possibilities offered by a play, he is able to explore a wider variety of perspectives than the conceptual logic Scholasticism allows for. The outcome of the clash between Nature and Grace is never in doubt. Vondel lived long enough to see the publication, in 1678, of Adriaan Beverland's Peccatum Originale (Original $\mathrm{Sin}$ ), in which a rare, explicitly libertine reading of Spinoza inspired the author to propose an interpretation of the Fall, glorifying man's natural desire to have sex. ${ }^{43}$ We don't know how Vondel reacted to this book; perhaps he never saw a copy. But while he was fully entitled to feel that in his biblical tragedies he had already provided a wholesome reply to this 'Spinozist eroticism', Noah, on the other hand, and the character of Urania in particular also suggest that Beverland's views may well have put a smile on his face, if only fleetingly. Being a great playwright, Vondel did not shy away from articulating perspectives that he himself was supposed to condemn with such rhetorical panache that until the end of the play, the tension between Nature and Grace remains intact.

In the Dedication to Noah, Vondel naturally reinforces the necessity to combat the atheists, including their denial of the historical accuracy of Moses's account of the Flood. Vondel does not merely want to convince them of the error of their ways, he claims, for how could a play

want indien / Men hier de wiskunst eischt, om toonbaer te bediên, / Door maeten en getal, den eigen aert der zielen, / Die noit, als't lijf, in 't lot der sterflijckheit vervielen; / Dat waer een onbescheit. men eisch' geen' klaerder dagh / Van reden dan de zaeck natuurlijck geven magh, / En dit vernoeght een hart, dat niet, als ziende blinden, / Een tastbre reden eischt, die hier niet is te vinden' (III, 999-1018).

${ }^{42}$ Konst, "'Het goet of qaet te kiezen".

${ }^{43}$ See Elias, 'Het spinozistisch erotisme van Adriaan Beverland'; De Smet, Hadrianus Beverland (1650-1718); Israel, Radical Enlightenment, pp. 87-88; Leemans, Het woord is aan de onderkant, pp. 250-56. 
decide a dispute on the early history of the world? He also states it to have been his purpose to picture God's justice (Dedication, 73-76.). As it is precisely the justice of God's 'revenge' that is so severely being called into question in Noah, it remains to be seen what Noah is actually telling us. Perhaps the Bespiegelingen offer a clue to the theatrical logic ruling Noah, for Vondel's essay in Scholasticism reveals a particular emphasis on the female character of nature. Vondel repeatedly calls Nature 'a woman' (I, 143 and 910) and 'God's daughter' (I, 625). God's power, Vondel continues, produces 'everything' from the 'womb' ['schoot'] (I, 439-41) of nature, which remains passive until 'touched' by God. This is not to say that Vondel employed this scheme consistently in all of his work - in Adam in ballingschap (1l. 894-96), for instance, Adam compares Eve to the Moon, following him, the Sun but both in the Bespiegelingen and in Noah he does. In Noah, there is talk of 'vrou natuure' (1.214) as well, and Nature is said to have a woman at its helm (1. 793). But it also has, I should like to suggest, a spokesperson. For in Noah, it is Urania who most consistently speaks out on behalf of Nature's lawlessness, its abundance and the pleasures it procures. It seems no accident, that out of all of Noah's characters, Urania has invariably drawn most attention. In 1864, A.S. Kok felt compelled to call her the most hideous female character ever drawn by Vondel, a 'crude improbability', a 'monstrous exception. ${ }^{44}$ More recently, Jan Konst called her 'nymphomaniac.45 Schenkeveld-van der Dussen has warned against a misogynous reading of this play, although she too, emphasised the role that Vondel's female characters play as temptresses. ${ }^{46}$

It is true that we are told again and again that Cain's daughters are at the root of the destruction of the first world (1l. 56sqq.; 390), and Achiman cries out that 'vrouwenmin' (love of women) lies at the origins of all evil, once he recognises the end is nigh (1. 845). On the other hand, if Nature itself is female, shouldn't we perhaps conclude that in Noah's ultimate shame, it also triumphs in that it proves to be indomitable? This much seems clear: that if human reason, evidently male in its conception, is ultimately unable to account for the reasons God may

\footnotetext{
${ }^{44} \mathrm{Kok}$, Vondel in eenige van zijn vrouwenkarakters, p. 17: 'een grove onwaarschijnlijkheid', 'een monsterachtige uitzondering', 'de afzichtelijkste vrouwenfiguur [...] die Vondel ooit getekend heeft.'

${ }^{45}$ Konst, Determinatie en vrije wil, p. 20.

${ }^{46}$ Schenkeveld-van der Dussen, Vondel en 't vrouwelijk dier, pp. 16-23.
} 
have had - firstly to allow for the rise of evil, and finally for administering Grace - it remains to be seen who in Noah should be deemed the weaker sex. Only if we compare Urania to Noah himself, who is a man of God and therefore not entirely 'of this world', she has found her match. Compared to Achiman, who turns out to be a coward and cannot make up his mind for himself, Urania seems definitely superior. At the very end of the play, of course, she begs for mercy as well, for being human; even she has to succumb to the authority of her Maker, but to her credit, she is the last of the play's characters to do so. 